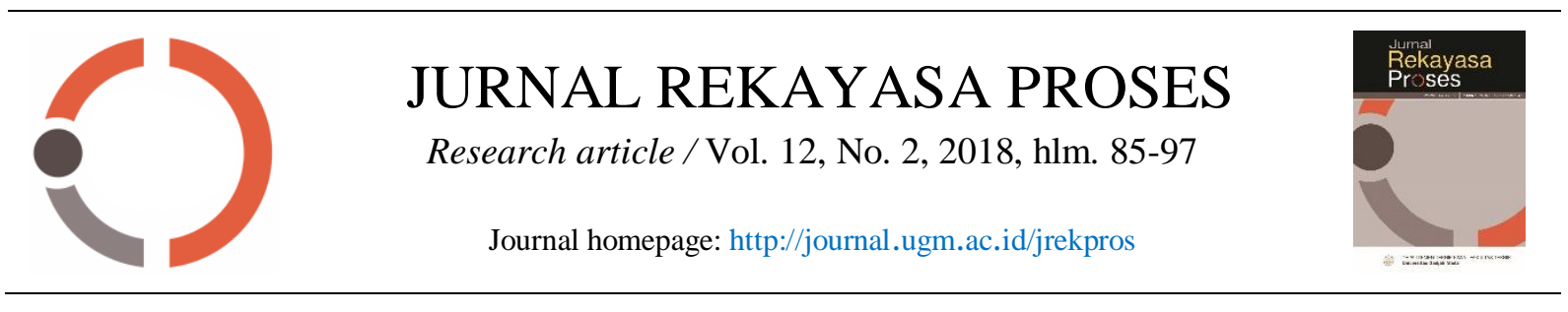

\title{
Kajian Dampak Lingkungan pada Sistem Produksi Listrik dari Limbah Buah Menggunakan Life Cycle Assessment
}

\author{
Fajar Marendra $^{1 *}$, Anggun Rahmada ${ }^{2}$, Agus Prasetya $^{3}$, Rochim B. Cahyono ${ }^{3}$ dan Teguh Ariyanto ${ }^{3 *}$ \\ ${ }^{1}$ Magister Teknologi untuk Pengembangan Berkelanjutan, Program Studi Ilmu Lingkungan, Sekolah \\ Pascasarjana, Universitas Gadjah Mada \\ Jl. Teknika Utara, Pogung, Mlati, Kampus UGM, Yogyakarta, 55281 \\ ${ }^{2}$ Waste Refinery Center, Fakultas Teknik, Universitas Gadjah Mada \\ Jl Grafika No. 2 Kampus UGM, Yogyakarta, 55281 \\ ${ }^{3}$ Departemen Teknik Kimia, Fakultas Teknik, Universitas Gadjah Mada \\ Jl Grafika No. 2 Kampus UGM, Yogyakarta, 55281 \\ *Alamat korespondensi: fajar.marendra@gmail.com, teguh.ariyanto@ugm.ac.id
}

(Submisi 22 Juni 2018 ; Revisi 2 November 2018 ; Penerimaan 5 November 2018)

\section{A B S T RACT}

Producing biogas by anaerobic digestion $(A D)$ is a promising process that can simultaneously provide renewable energy and dispose solid waste safely. However, this process could affect environment e.g. due to greenhouse gas emissions. By life cycle assessment (LCA), we assessed the environmental impact (EI) of an integrated fruit waste-based biogas system and its subsystems of Biogas Power Plant Gamping. Data were collected from an actual plant in Gamping, Sleman, Yogyakarta, Indonesia that adopted a wet $A D$ process at mesophilic condition. The results showed that the global warming potential (GWP) emission of the system reached $81.95 \mathrm{kgCO}_{2}$-eq/t, and the acidification potential (AP), eutrophication potential (EP), human toxicity potential (HTPinf) and fresh water ecotoxicity (FAETPinf) emissions were low. The EI was mainly generated by two subsystems, namely, the electricity generation and the digestate storage. A comparison analysis showed that the GWP become the main contributor of environmental loads produced by Biogas Plant Gamping, Suazhou Biogas Model, Opatokun Biogas Model, Opatokun Pyrolisis Model, dan Opatokun Integrated System Anaerobic Digestion and Pyrolisis. The GWP impact control and reduction could significantly reduce the EI of the system. It has been shown that improving the technology of the process, the electricity generation and the digestate storage will result in the reduction of EI of the biogas system.

Keywords: environmental impact; fruit waste; life cycle assessment (LCA); renewable energy.

\section{A B S T R A K}

Produksi listrik dari biogas dengan anaerobic digestion (AD) merupakan proses yang menjanjikan karena dapat menghasilkan energi listrik dan penanganan limbah padat dengan aman. Namun, proses ini mempengaruhi lingkungan akibat emisi gas rumah kaca. Penilaian dampak lingkungan (environmental impact atau EI) sistem biogas berbasis limbah terpadu dan subsistemnya terhadap Biogas Power Plant Gamping (BPG) dilakukan dengan metode life cycle assesement atau LCA. Data dikumpulkan dari plant yang sebenarnya di Gamping, Sleman, Yogyakarta, Indonesia yang mengadopsi proses AD basah pada kondisi mesofilik. Potensi pemanasan global (global warming potential atau GWP) dari sistem mencapai $81,95 \mathrm{kgCO}_{2}$-eq/t, sedangkan potensi keasaman (acidification potential atau AP), potensi eutrofikasi (eutrophication potential atau EP), potensi toksisitas manusia (human toxicity potential atau HTPinf) dan ekotoksisitas air (fresh water ecotoxicity 
atau FAETPinf) potensi emisinya cukup rendah. Potensi EI terutama dihasilkan oleh dua subsistem, yaitu, pembangkit listrik dan penyimpanan digestate. Analisis perbandingan menunjukkan bahwa dampak GWP menjadi kontributor utama dari beban lingkungan yang dihasilkan oleh Biogas Plant Gamping, biogas model Suazhou, biogas model Opatokun, model pirolisis Opatokun, serta model integrasi AD dan pirolisis Opatokun. Pengendalian dan pengurangan dampak GWP secara signifikan dapat mengurangi EI dari sistem. Telah terbukti bahwa peningkatkan teknologi proses, pembangkit listrik dan penyimpanan digestate akan menghasilkan pengurangan EI dari sistem biogas.

Kata kunci: dampak lingkungan; energi terbarukan; life cycle assessment (LCA); limbah buah

\section{Pendahuluan}

Energi terbarukan dianggap sebagai langkah strategis yang digunakan sebagai upaya penurunan potensi perubahan iklim dan kelangkaan energi melalui konsep berkelanjutan (Cong, 2013; Hua dkk, 2016). Banyak negara yang berkomitmen untuk mengimplementasikan energi terbarukan guna mengurangi emisi dan memenuhi suplai energi dalam negerinya (Poeschlv dkk., 2010; Codina Gironès dkk., 2017). Indonesia sebagai negara terbesar di Asia Tenggara tidak mau ketinggalan dalam tren energi terbarukan ini. Indonesia menargetkan penggunaan energi terbarukan mencapai $17 \%$ pada tahun 2025 (Dewan Energi Nasional, 2014).

Produksi biogas menggunakan teknologi anaerobic digestion (AD) sampai saat ini masih menjadi topik menarik dalam upaya penanganan masalah lingkungan sekaligus pemanenan energi terbarukan (Jin dkk., 2015; Williams dkk., 2016; Zhang dkk., 2016; Chen dkk., 2017). Penerapan teknologi $\mathrm{AD}$ memberikan kesempatan dan potensi untuk mendapatkan dua solusi sekaligus terkait masalah yang saat ini sedang dihadapi oleh dunia yaitu lingkungan dan energi. Banyak penelitian dengan fokus utama optimasi produksi biogas telah dilakukan (Ahn dkk., 2010; Saady \& Massé, 2015; Lijó dkk., 2017) sebagai upaya mendukung ketahanan energi dunia. Beberapa penelitian terkait pengembangan biogas pun telah banyak dilakukan di Indonesia seperti yang dilakukan oleh Cahyari dan Putra, (2009), Rahmani dkk. (2013), dan Zalizar dkk. (2013). Biogas berbasis limbah pun menjadi salah satu topik yang dikerjakan oleh beberapa peneliti di Indonesia seperti Nasir dkk. (2012), Sitorus dkk. (2013), dan Ariyanto dkk. (2017).

Waste Refinery Center (WRC), Badan Perencanaan Pembangunan Daerah (Bappeda)
Sleman, Koperasi Gemah Ripah dan Pemerintah Swedia pada tahun 2011 meluncurkan biogas plant berbasis limbah buah di Pasar Gemah Ripah, Sleman, Yogyakarta. Program ini merupakan upaya untuk menjalankan amanat UU No. 18 tahun 2008 tentang pengelolaan sampah serta dukungan terhadap pemerintah untuk penggunaan energi terbarukan di Indonesia. Biogas Plant Gamping (BGP) merupakan biogas plant pertama yang mengolah sampah pasar tradisional Indonesia menjadi energi dan masih bertahan sampai saat ini. Biogas plant ini menggunakan $100 \%$ limbah buah sebagai bahan bakunya. Energi yang dihasilkan digunakan untuk memenuhi kebutuhan penerangan dan memasak seluruh warga pasar. Sementara digestate yang dihasilkan digunakan sebagai bahan baku pembuatan pupuk organik.

Menurut Kloepffer (2008), sebagai sebuah entitas yang berdampingan dengan entitas lain, dapat dipastikan produksi biogas berbasis limbah pun memiliki dampak pada aspek lingkungan yang merupakan parameter keberlanjutan. Kajian terkait peran dari produksi energi dalam upaya mengatasi masalah lingkungan penting untuk dilakukan guna menjaga keberlanjutan dan eksistensi dari entitas tersebut. Masih belum banyak penelitian dengan topik kajian aspek lingkungan dan komparasinya dengan teknologi produksi energi berbasis limbah organik yang lain. Beberapa penelitian lain mengkaji terkait teknologi produksi biogas seperti yang dilakukan oleh Kaparaju dkk. (2008), Kothari dkk. (2014), dan Scano dkk. (2014) serta terkait pemurnian biogas atau konversi biogas menjadi biometana dilakukan oleh Makaruk dkk. (2013), Niesner dkk. (2013), Schiavon Maia dkk. (2014), dan Miltner dkk. (2017). 
Artikel ini bertujuan untuk melakukan analisis mendalam terkait aspek manfaat lingkungan pada konversi energi berbasis limbah di Indonesia dengan Biogas Plant Gamping sebagai model dalam pemanfaatan limbah yang dibandingkan dengan teknologi produksi energi berbasis limbah lainnya.

\section{Metode Penelitian}

\subsection{Produksi Energi Terbarukan Berbasis Limbah Organik}

Produksi energi terbarukan berbasis limbah buah yang dikaji dalam kajian ini adalah Biogas Power Plant Gamping (BPG) yang terletak dalam satu area dengan Pasar Gemah Ripah (PGR), Gamping, Sleman, Yogyakarta. Proyek biogas Gamping merupakan bagian penting dalam pengelolaan sampah pada sumbernya. Unit dengan kapasitas bahan baku 4 ton sampah per hari ini secara resmi telah beroperasi sejak Februari 2011. Unit ini memiliki potensi biogas sebanyak $162 \mathrm{Nm}^{3}$ dengan hasil konversi listrik sebesar $150 \mathrm{kWh} /$ hari.

BPG dibangun atas inisiasi dari Universitas Gadjah Mada (UGM), Pemerintah Daerah Sleman dan Koperasi Pasar Gemah Ripah bekerja sama dengan pihak Swedia, yaitu University of Borås, Borås Municipality, dan Borås Energy and Environment. Perancangannya didasarkan pada hasil riset dari UGM dikombinasi dengan pengalaman teknis pihak Swedia. Saat ini sebagian besar biogas yang dihasilkan dari unit tersebut digunakan untuk menggerakkan generator listrik yang dimanfaatkan untuk penerangan pasar dan sebagian lagi digunakan langsung untuk kebutuhan memasak di warungwarung yang ada di pasar tersebut. Pembangunan BPG ini merupakan salah satu upaya dalam memberikan kesadaran tentang pemanfaatan sampah dengan cara membangun pilot plant yang mengkonversi sampah menjadi produk yang berguna. Program dimulai tahun 2006 dengan proses edukasi melalui berbagai macam workshop dan roadshow di beberapa kota besar. Inisiasi BPG dilakukan pada tahun 2008 dengan dukungan finansial utama dari NUTEK SIDA.
Sebagai pasar induk buah terbesar di Yogyakarta, PGR menghasilkan 3600 ton limbah setiap tahun. Apabila limbah ini tidak ditangani dengan benar, masalah lingkungan yang serius dapat terjadi. Dengan menggunakan teknologi anaerobic digestion untuk menghasilkan biogas dan listrik, PGR memecahkan masalah pembuangan limbah sekaligus menciptakan manfaat sosial dan lingkungan yang potensial. Sebagai model komersial untuk memanfaatkan sumber daya secara komprehensif, PGR mengintegrasikan pasar buah, eduwisata, biogas, listrik dan pupuk organik. Biogas plant yang dilengkapi dengan teknologi rekomendasi Universitas Gadjah Mada, University of Borås, Borås Municipality, dan Borås Energy and Environment memungkinkan pengelolaan limbah yang optimal dan mandiri, mengenalkan dan mendukung program energi terbarukan serta berkonstribusi dalam pengembangan berkelanjutan.

Biogas Power Plant Gamping merupakan unit dari PGR yang melakukan proses peruraian secara anaerob terhadap limbah untuk memproduksi biogas, listrik dalam rangka pengelolaan limbah buah. Proses teknologi pada Biogas Plant Gamping terdiri dari empat komponen utama: pretreatment bahan baku, anaerobic digestion unit, unit pembangkit dan jaringan listrik, unit penyimpanan digestate untuk pupuk organik (Gambar 1).

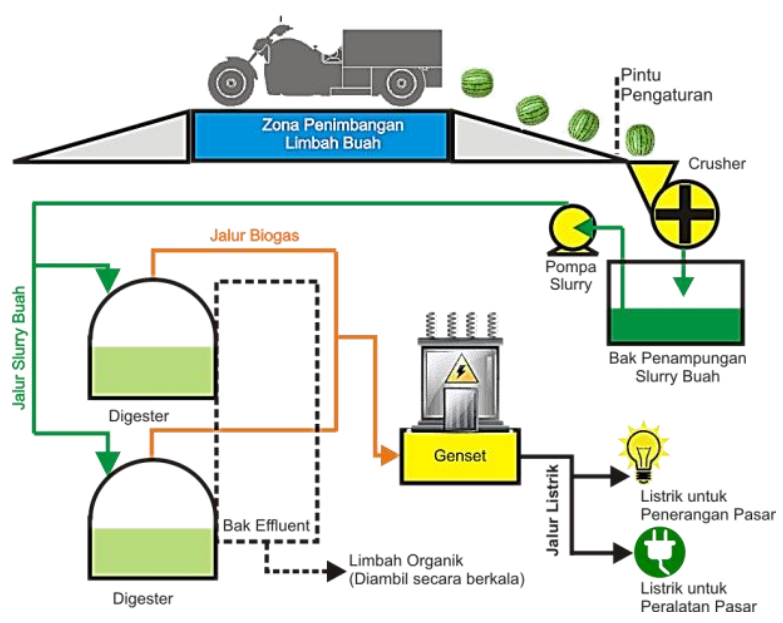

Gambar 1. Diagram alir pengolahan limbah organik BPG 
Pemantauan manajemen produksi biogas dilakukan pada seluruh proses melalui serangkaian sistem integrasi pemantauan yang sedang diupayakan dapat diakses secara daring melalui biogasgamping.com. Sebagai salah satu komponen utama dari pengelolaan dan pengolahan limbah di Pasar Gemah Ripah, proyek biogas telah memberikan manfaat lingkungan.

Berdasarkan pengamatan di lapangan, komunikasi dengan penanggung jawab biogas plant serta mempelajari berkas-berkas biogas plant dapat diketahui bahwa bahan baku yang digunakan untuk membangkitkan listrik adalah sampah buah. Terdapat dua unit digester masingmasing berukuran $100 \mathrm{~m}^{3}$ dengan tipe fixed dome tanpa pengaduk. Digester bekerja pada suhu mesofilik dan $\mathrm{pH}$ operasi antara 6,2-6,5. Tekanan yang digunakan adalah $110 \mathrm{cmH}_{2} \mathrm{O}$ tanpa ada penampungan gas diluar, sehingga apabila biogas didalam digester memiliki tekanan melebihi 110 $\mathrm{cmH}_{2} \mathrm{O}$ maka akan rilis otomatis ke lingkungan. Organic loading rate mencapai $4.000 \mathrm{~kg} / \mathrm{hari}$ dan waktu retensi sekitar 25-30 hari.

Sampah buah sebanyak $4.000 \mathrm{~kg}$ ditimbang dalam unit penimbangan kemudian dipindahkan menuju alat pencacah (crusher) untuk dicacah hingga lembut. Air sebanyak $4.000 \mathrm{~kg}$ ditambahkan selama proses pencacahan. Campuran air dan sampah buah sebanyak 8.000 $\mathrm{kg}$ dialirkan menuju kolam penampungan sementara untuk diaerasi selama 30 menit. Sebanyak $8.000 \mathrm{~kg}$ campuran air dan sampah buah dipompa dengan pompa P-01 menuju reaktor R-01 dan R-02 untuk mendapatkan perlakuan fermentasi anaerobik.

Di dalam reaktor R-01 dan R-02 terjadi proses anaerobik yang tidak membutuhkan udara membentuk biogas sebagai produk utama dan digestate sebagai bahan pembuatan pupuk. Tahapan proses yang terjadi di dalam digester secara berurutan adalah: hidrolisis, asidogenesis, asetogenesis dan metanogenesis.

Biogas yang terbentuk dari proses anaerobik di dalam digester sebanyak $162 \mathrm{Nm}^{3}$ dialirkan melalui pipa menuju unit pembangkit listrik untuk dikonversi menjadi listrik. Sementara digestate dialirkan menuju bak pelimpahan untuk diendapkan. Cairan digestate dipompa menuju tangki penampungan, kemudian dialirkan menuju tangki fermentasi untuk digunakan sebagai pupuk cair organik.

\subsubsection{Unit pretreatment}

Unit ini terdiri dari unit penimbangan dan penghancuran. Unit penimbangan ini terdiri dari sebuah pelat timbangan berdimensi $1,5 \mathrm{~m} \times 2,5 \mathrm{~m}$ dengan layar instrumen yang menampilkan berat kendaraan pengangkut sampah dan sampah yang masuk. Sampah buah diangkut menggunakan kendaraan roda tiga kemudian ditimbang di dalam unit penimbangan lalu di masukkan ke dalam penampungan sementara sebelum dilakukan pengecilan ukuran pada unit penghancuran. Unit penghancuran memiliki dua buah crusher yang berbeda peruntukannya. Satu crusher yang berukuran besar digunakan untuk mencacah buah buahan lunak dan sedikit serat, satu crusher yang berukuran kecil digunakan untuk mencacah khusus buah mangga dan buahbuahan yang memiliki karakter serabut. Kapasitas pencacahan untuk crusher besar 1.000 $\mathrm{kg} / \mathrm{jam}$ semetara yang kecil 300 kg/jam.

\subsubsection{Unit anaerobic digestion}

Unit ini berupa dua unit biodigester berukuran masing-masing $100 \mathrm{~m}^{3}$. Reaktor bertipe fixed dome dengan tekanan maksimal $110 \mathrm{cmH}_{2} \mathrm{O}$. ketika tekanan biogas di dalam reaktor melebihi $110 \mathrm{cmH}_{2} \mathrm{O}$ maka akan rilis secara otomatis ke lingkungan. Sistem ini menerapkan anaerobic digestion sehingga harus dipastikan terbebas dari oksigen. Digester ini dirancang untuk mengolah limbah sebanyak 4 ton/hari. Unit ini dilengkapi dengan sensor $\mathrm{pH}$, tekanan, kandungan metana dan karbondioksida.

\subsubsection{Unit pembangkit listrik dan jaringan listrik}

Unit ini bertugas untuk mengonversi biogas menjadi energi listrik yang dapat digunakan untuk kebutuhan pasar. Unit ini didukung oleh dua unit generator dengan kapasitas masingmasing 6 KVA. Satu unit flowmeter gas, tiga unit scrubber/water trap, 1 unit data logger, 1 unit power meter dan 1 paket instalasi jaringan listrik 
yang tersambung ke 155 kios pasar dengan jatah masing-masing kios dua titik lampu.

\subsubsection{Unit penyimpanan digestate untuk pupuk organik.}

Pembuatan pupuk organik dilakukan pada unit ini. Dengan fasilitas 3 unit tangki fermentasi, satu unit tangki penampungan sementara, dan dua unit hidroponik percontohan. Unit ini bertanggung jawab terhadap proses fermentasi pengolahan pupuk organik dan aplikasinya di hidroponik atau lahan pertanian.

\subsection{Penentuan Batasan Sistem}

Dalam rangka meminimalisasi timbulnya dampak non-teknis selama proses analisis, maka proses timbulan sampah, pengumpulan dan transportasi sampah serta pemanfaatan produk oleh konsumen tidak termasuk dalam topik penelitian. Batasan sistem dalam kajian ini ditunjukkan oleh Gambar 2. Kajian ini hanya mengkaji objek kajian sampai tahap midpoint dengan jangkauan penelitian berupa gate to gate system. Batas sistem yang diterapkan pada kajian ini mengacu pada proses pengolahan limbah organik berupa limbah buah sebagai input material, energi terbarukan dan digestate sebagai output material.

Sistem ini terdiri dari terminal input (sampah buah dan air), main treatment, terminal output (menghasilkan biogas, listrik dan penyimpanan digestate). Untuk penilaian efisiensi lingkungan digunakan data aktual dari sistem yang telah dijelaskan pada subbab 2.1 sepanjang JanuariFebruari 2017. Hasil rerata input material ditunjukkan oleh Gambar 2.
Aliran material dan energi dari proyek ini sangat dipengaruhi oleh karakteristik dari limbah buah yang dihasilkan oleh Pasar Gemah Ripah. Karakterisasi buah telah dilakukan oleh Nurrihadini (2009). Sifat fisika dan kimia buah ditunjukkan oleh Tabel 1.

Tabel 1. Sifat fisika dan kimia limbah buah

\begin{tabular}{|c|c|c|c|c|c|c|c|}
\hline \multirow{2}{*}{ No } & \multirow{2}{*}{ Buah } & \multicolumn{3}{|c|}{ Persentase $(\%)$} & \multicolumn{3}{|c|}{ Persentase $(\%)$} \\
\hline & & M & VS & $\mathrm{DM}$ & karbohidrat & lemak & protein \\
\hline 1 & Jeruk & 88,6 & 11,4 & 11,0 & 51,1 & 11,4 & 37,6 \\
\hline 2 & Mangga & 87,9 & 12,1 & 10,1 & 49,3 & 11,0 & 36,3 \\
\hline 3 & Apel & 86,3 & 13,7 & 13,3 & 38,8 & 8,7 & 28,3 \\
\hline 4 & Nanas & 89,6 & 10,4 & 10,2 & 51,1 & 11,4 & 37,6 \\
\hline 5 & Semangka & 95,9 & 4,1 & 3,3 & 61,9 & 13,8 & 45,5 \\
\hline 6 & Melon & 95,4 & 4,5 & 4,2 & 92,9 & 22,5 & 74,3 \\
\hline 7 & Anggur & 83,2 & 16,8 & 14,6 & 27,1 & 6,1 & 19,9 \\
\hline 8 & Salak & 85,8 & 14,2 & 11,1 & 33,0 & 7,4 & 24,3 \\
\hline 9 & Alpukat & 85,7 & 14,3 & 13,7 & 33,7 & 7,5 & 24,8 \\
\hline 10 & Kelengkeng & 83,0 & 17,0 & 16,1 & 27,3 & 6,1 & 20,1 \\
\hline 11 & Belimbing & 92,3 & 7,7 & 7,0 & 61,2 & 13,7 & 45,1 \\
\hline 12 & Rambutan & 84,0 & 16,0 & 15,8 & 28,2 & 6,3 & 20,7 \\
\hline 13 & Pepaya & 93,8 & 6,2 & 5,3 & 79,2 & 17,7 & 58,3 \\
\hline 14 & Jambu air & 92,8 & 7,2 & 6,8 & 67,6 & 15,1 & 49,8 \\
\hline 15 & Jambu biji & 90,5 & 9,5 & 7,6 & 49,5 & 11,1 & 36,4 \\
\hline 16 & Manggis & 87,9 & 12,1 & 11,2 & 37,0 & 8,3 & 27,3 \\
\hline
\end{tabular}

(Nurrihadini, 2009)

\subsection{Metode Analisis}

Kajian ini menggunakan metode life cycle assessment (LCA) yang terdiri dari empat tahapan untuk mengevaluasi dampak lingkungan dari proses pengolahan limbah organik.

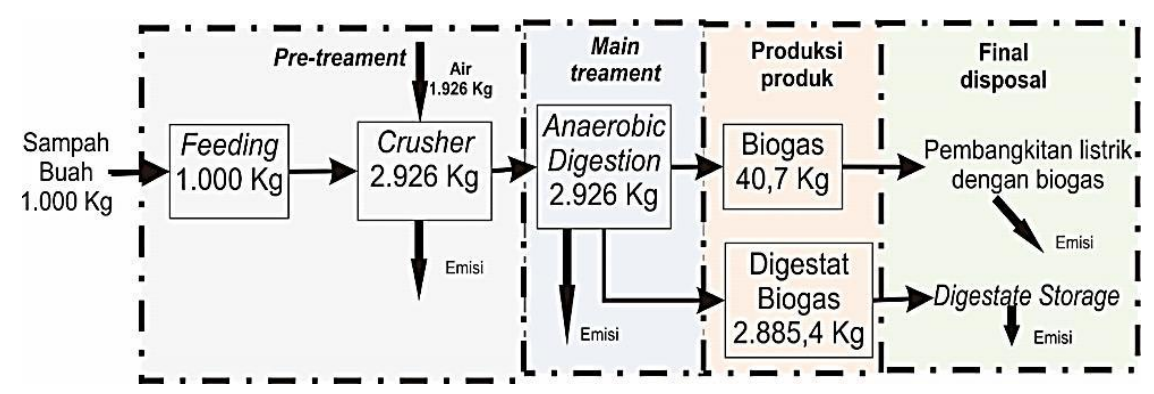

Gambar 2. Batasan sistem LCA Biogas Plant Gamping 


\subsubsection{Goals and scope definition}

Kajian ini bertujuan untuk mengevaluasi implikasi lingkungan dari operasional pengolahan sampah buah menggunakan teknologi anaerobic digester secara gate to gate sampai midpoint pada Biogas Plant Gamping. Analisis ini meliputi proses pengumpulan sampah, pengecilan ukuran sampah, anaerobic digestion, pembangkit listrik, dan digestate. Dalam studi siklus hidup, sistem dievaluasi berdasarkan fungsi yang ditetapkan (unit fungsional). Fungsi dari sistem yang dianalisis dalam kajian ini adalah mengolah sampah di Pasar Gemah Ripah Gamping. Unit fungsional yang dipilih untuk analisis ini adalah mengolah 1 ton sampah buah di Pasar Gemah Ripah Gamping.

Unit fungsional adalah 1 ton sampah yang diolah karena beberapa alasan. Basis ini memberikan hasil yang cukup besar untuk ditampilkan sebagai bilangan bulat dalam tabel hasil dan angka. Menggunakan unit yang lebih kecil, seperti satu kg sampah, akan memberikan hasil yang sangat kecil dan perlu ditunjukkan dalam notasi ilmiah. Hasil yang ditampilkan atas dasar 1 ton dapat dengan mudah dikonversi ke basis berat yang diinginkan. Misalnya, untuk mengonversi hasil per 1 ton ke hasil per $\mathrm{kg}$, bagi hasil $1000 \mathrm{~kg}$ dengan 1000 (untuk mencapai hasil per $\mathrm{kg}$ ).

\subsubsection{Life cycle inventory (LCI)}

Pengumpulan data didasarkan pada inspeksi lapangan pada situs produksi energi berbasis limbah organik, Biogas Plant Gamping, Waste Refinery Center, Standar Emisi Nasional, Badan Pusat Statistik dan database yang terdapat di Nielsen dkk., (2014), IPCC (2006), dan Nielsen dkk., (2010).

\subsubsection{Life cycle impact assessment (LCIA)}

Dalam kajian ini, metode midpoint telah diimplementasikan dengan menggunakan data dari Biogas Plant Gamping. Hal ini diharapkan dapat meningkatkan keakuratan hasil kajian. Beban lingkungan yang diprediksi diklasifikasikan dan dicirikan menjadi lima kategori dampak sebagai berikut: GWP (dalam $\mathrm{kg} \quad \mathrm{CO}_{2} \quad$ eq./kg), HTPinf (dalam $\mathrm{kg}$ 1,4diklorobenzena (1,4-DCB) eq./kg), ekotoksisitas air tawar (FAETPinf (dalam kg 1,4-DCB eq./kg), AP (dalam $\quad \mathrm{kg} \quad \mathrm{SO}_{2} \quad$ eq. $/ \mathrm{kg}$ ), dan potensi eutrofikasi (EP, dalam $\mathrm{kg} \mathrm{PO}_{4}{ }^{3-}$ eq./kg).

\subsubsection{Life cycle assesment interpretation (LCAI)}

Tahapan ini bertujuan untuk menginterpretasikan data yang telah dikumpulkan hasil kajian LCI dan LCIA menjadi beberapa hal yang dapat digunakan sebagai bahan untuk pengambilan keputusan dan kebijakan. Efek dari produksi energi berbasis limbah organik Biogas Plant Gamping didiskusikan berdasarkan hasil dari LCI dan LCIA. Saran operasi dan manajemen juga diberikan melalui LCAI.

\subsection{Analisis Perbandingan}

Untuk mendapatkan hasil yang adil, maka hasil LCIA dari Biogas Plant Gamping perlu dibandingkan dengan produksi energi berbasis limbah organik lainnya agar diketahui posisi dari Biogas Power Plant Gamping. Oleh karena itu, kajian ini membandingkan hasil LCIA dari empat model produksi energi berbasis limbah organik yaitu biogas model Suazhou, biogas model Opatokun, model pirolisis Opatokun, dan integrasi Opatokun anaerobic digestion dengan pirolisis. Komparasi dilakukan dalam lima kategori dampak yaitu: global warming potensial (GWP, dalam $\mathrm{kg} \mathrm{CO}_{2}$ eq./kg), human toxicity potensial-inf (HTPinf, dalam $\mathrm{kg}$ 1,4diklorobenzena (1,4-DCB) eq./kg), ekotoksisitas air tawar (FAETPinf, dalam kg 1,4-DCB eq./kg), Acidification Potensial (AP, dalam $\mathrm{kg} \quad \mathrm{SO}_{2}$ eq. $/ \mathrm{kg}$ ), dan potensi eutrofikasi (EP, dalam $\mathrm{kg}$ $\mathrm{PO}_{4}{ }^{3-}$ eq. $/ \mathrm{kg}$ ). Dengan adanya analisis perbandingan ini, Biogas Plant Gamping dapat melakukan perbaikan berdasarkan hasil perbandingan dengan model produksi energi terbarukan berbasis limbah organik di dunia. 


\section{Hasil dan Pembahasan}

\subsection{Hasil dan Analisis Life Cycle Assessment}

Beban lingkungan BPG dari hasil LCI pada Tabel 2, dihitung dan dikelompokan menggunakan faktor dampak dari masing-masing emisi yang dihasilkan. Hasil perhitungan beban lingkungan BPG ditunjukkan oleh Tabel 3. Indikator kategori yang terpilih disajikan secara terpisah karena masing-masing kategori memiliki unit referensi yang berbeda.

Sistem produksi energi terbarukan berbasis limbah organik BPG, memberikan dampak negatif terhadap lingkungan. Beban lingkungan yang terbesar diberikan oleh GWP yang mencapai 81,95 $\mathrm{kg} \mathrm{CO}_{2 \mathrm{eq}} / \mathrm{T}$, diikuti oleh dampak AP yang relatif rendah $\left(0,07 \quad \mathrm{~kg} \quad \mathrm{SO}_{2} \mathrm{eq} / \mathrm{t}\right)$, dampak EP yang relatif rendah $\left(0,02 \mathrm{~kg} \mathrm{PO}_{4}{ }^{3-}\right.$ eq/t), dampak HTP dan FAETP yang sangat rendah $(0,0109 \mathrm{~kg} 1,4 \mathrm{DCBeq} / \mathrm{t}$ dan $0,0098 \mathrm{~kg}$ 1,4 DCBeq/t). Oleh karena itu, Sistem produksi energi terbarukan berbasis limbah organik BPG memberikan beban lingkungan berupa emisi gas rumah kaca, toksisitas akuatik, HTP, EP dan AP.

Global warming potensial merupakan dampak lingkungan berupa peningkatan suhu bumi atau biasa disebut pemanasan global yang disebabkan oleh gas $\mathrm{CO}_{2}, \mathrm{CH}_{4}, \mathrm{~N}_{2} \mathrm{O}$ dan sebagainya. Pemanfaatan limbah buah menjadi biogas, listrik dan pupuk organik sebenarnya menurunkan sebagian besar potensi pemanasan global. Hanya saja penggunaan energi dan penyimpanan digestate dalam proses yang terjadi pada sistem BPG memberikan andil yang signifikan terhadap nilai beban lingkungan. Analisis subsistem menunjukkan bahwa penyimpanan digestate untuk produksi pupuk organik memberikan konstribusi tertinggi yaitu sebesar $45,51 \mathrm{~kg}$ $\mathrm{CO}_{2 e q} / \mathrm{T}$ sebagaimana ditunjukkan Gambar 3 . Hal ini terjadi karena proses penyimpanan digestate menurut Hamelin dkk. (2013) memberikan potensi pencemaran yang besar. Hal ini terjadi sangat mungkin dikarena proses degradasi biologis masih terjadi dalam proses penyimpanan digestate dan emisi yang dihasilkan langsung rilis ke lingkungan. Emisi GWP yang kecil menempatkan AD ikut andil dalam upaya penurunkan emisi gas rumah kaca sebesar $899 \mathrm{~kg}$
$\mathrm{CO}_{\text {2eq }} /$ ton sampah buah yang diolah dari TPA. Hal ini selaras dengan laporan Pathak dkk. (2009) yang menyatakan bahwa saat ini 3,83 juta biogas power plant beroperasi di India dapat mengurangi pemanasan global sebesar $37 \mathrm{Mt}$ $\mathrm{CO}_{2 \mathrm{eq}}$ /tahun.

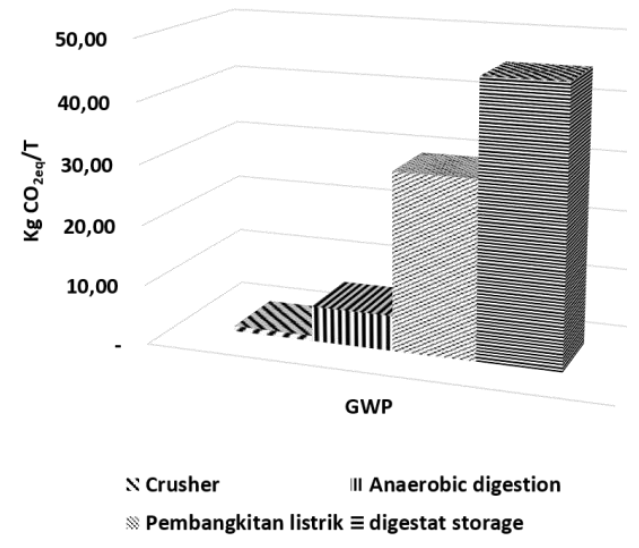

Gambar 3. Analisis konstribusi empat subsistem terhadap dampak GWP

Potensi ekotoksisitas pada kajian ini mempertimbangkan dampak zat beracun terhadap ekologi akuatik (FAETP) dan kesehatan manusia (HTP). Nilai ini dinyatakan dalam $\mathrm{kg}$ 1,4diklorobenzena ( $\mathrm{kg}$ 1,4-DCBeq.). Nilai dampak toksisitas FAETP dan HTP dari BPG menunjukkan angka yang mendekati nol $(0,0098$ dan 0,109). Hal ini menunjukkan BPG hampir tidak memberikan dampak zat beracun yang signifikan terhadap ekologi akuatik dan kesehatan manusia. Konstribusi terbesar dampak FAETP dan HTP dihasilkan oleh unit pembangkit listrik dikarenakan hanya proses pembangkitan listrik saja yang menghasilkan zat beracun (Nielsen dkk., 2010) meski dalam jumlah yang sangat kecil. Unit operasi yang lain seperti unit crusher, unit anaerobic digestion dan penyimpanan digestate tidak menghasilkan konstribusi yang signifikan sebagaimana ditunjukkan oleh Gambar 4.

Potensi asidifikasi muncul akibat aktivitas manusia yang menghasilkan emisi berupa unsur $\mathrm{S}$ dan $\mathrm{N}$ termasuk di dalamnya $\mathrm{NO}_{x}$ dan $\mathrm{NH}_{3}$. Nilai potensi ini dinyatakan dalam $\mathrm{kg} \mathrm{SO}_{2}$ eq. Sebagaimana ditunjukkan oleh Gambar 5, dampak AP dihasilkan oleh unit penyimpanan digestate sebagai konstributor utama sebesar 
$0,056 \mathrm{~kg} \mathrm{SO}_{2}$ eq/T diikuti oleh pembangkit listrik sebesar 0,014 $\mathrm{kg} \mathrm{SO}_{2}$ eq/T. Hal ini terjadi karena potensi emisi $\mathrm{SO}_{2}, \mathrm{NO}_{\mathrm{x}}$ dan $\mathrm{NH}_{3}$ pada unit penyimpanan digestate masih dapat terjadi akibat proses fermentasi yang terjadi pada unit ini. Berdasarkan Tabel 3, nilai dampak AP yang dihasilkan oleh BPG mendekati nol yaitu sebesar $0,07 \mathrm{~kg} \mathrm{SO}{ }_{2}$ eq/T. Hal ini menunjukkan bahwa BPG tidak memberikan dampak signifikan pada potensi asidifikasi.

Nilai dampak EP menggambarkan potensi dampak yang menimbulkan tumbuhnya tanaman secara berlebihan pada perairan karena penambahan nutrien dari jenis nitrogen dan fosfor. Ciri suatu perairan mengalamai eutrofikasi adalah keberadaan ganggang air yang akan mengurangi nutirisi kebutuhan hewan dan tanaman air, air berwarna hijau, kuning, cokelat, bahkan merah serta keruh. Dekomposisi ganggang air oleh bakteri membutuhkan banyak oksigen yang berefek pada kematian organisme air akibat kekurangan oksigen. Nilai dampak ini dihitung dengan faktor emisi dalam Heijungs dkk. (1992) dan dinyatakan dalam $\mathrm{kg} \mathrm{PO}_{4}^{3-}$ eq.
Konstributor utama dari penghasil dampak EP adalah penyimpanan digestate $(0,02)$ diikuti oleh pembangkit listrik $(0,0038)$. Tabel 3 menunjukan hasil bahwa BPG hanya memberikan dampak eutrofikasi sangat rendah bahkan mendekati nol $\left(0,02 \mathrm{~kg} \mathrm{PO}_{4}{ }^{3} \mathrm{eq} / \mathrm{T}\right)$.

Berdasarkan analisis konstribusi, subsistem BPG yang menjadi kontributor beban lingkungan di semua parameter dampak lingkungan adalah unit pembangkitan listrik. Unit penyimpanan digestate berada di posisi kedua dengan berkonstribusi terhadap dampak GWP, AP dan EP. Sementara unit crusher dan digester memberikan dampak negatif terhadap lingkungan berupa GWP namun memberikan dampak positif terhadap lingkungan pada aspek FAETP, HTP, AP dan EP. Untuk mengurangi dampak GWP dari operasional teknologi AD langkah-langkah tertentu dapat diambil diantaranya penyediaan gas holder yang lebih besar untuk menampung biogas yang dihasilkan dan penyediaan generator yang lebih ramah lingkungan dan berdaya lebih besar.

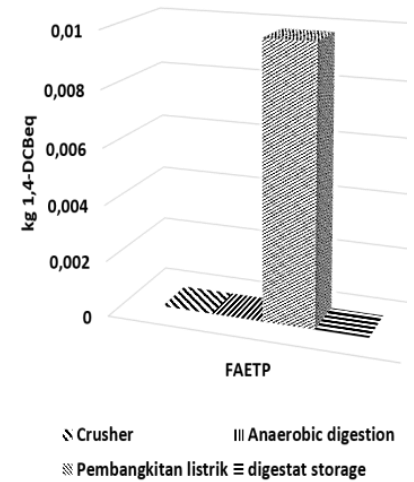

Gambar 4. Analisis konstribusi empat subsistem terhadap dampak HTP dan FAETP
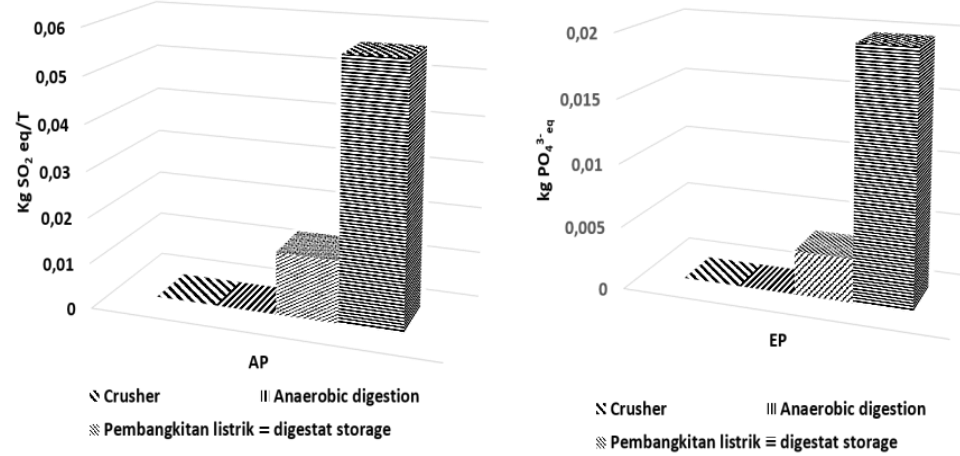

Gambar 5. Analisis konstribusi empat subsistem terhadap dampak AP dan EP 
Tabel 2. Hasil LCI Biogas Power Plant Gamping

\begin{tabular}{|c|c|c|}
\hline Emisi & Emisi & Nilai \\
\hline $\mathrm{CO}_{2}, \mathrm{~kg} / \mathrm{t}$ & $33,37 \times 10^{0} \mathrm{~Pb}, \mathrm{~kg} / \mathrm{t}$ & $6,68 \times 10^{-10}$ \\
\hline $\mathrm{CO}, \mathrm{kg} / \mathrm{t}$ & $4,14 \times 10^{-2} \mathrm{Sb}, \mathrm{kg} / \mathrm{t}$ & $1,60 \times 10^{-8}$ \\
\hline $\mathrm{CH}_{4}, \mathrm{~kg} / \mathrm{t}$ & $1,91 \times 10^{0} \mathrm{Se}, \mathrm{kg} / \mathrm{t}$ & $2,81 \times 10^{-8}$ \\
\hline NMVOC, $\mathrm{kg} / \mathrm{t}$ & $1,34 \times 10^{-3} \mathrm{Ti}, \mathrm{kg} / \mathrm{t}$ & $2,81 \times 10^{-8}$ \\
\hline $\mathrm{NH}_{3}, \mathrm{~kg} / \mathrm{t}$ & $\mathrm{V}, \mathrm{kg} / \mathrm{t}$ & $5,35 \times 10^{-9}$ \\
\hline $\mathrm{N} 2 \mathrm{O}, \mathrm{kg} / \mathrm{t}$ & $2,14 \times 10^{-4} \mathrm{Zn}, \mathrm{kg} / \mathrm{t}$ & $5,28 \times 10^{-7}$ \\
\hline $\mathrm{NO}_{\mathrm{x}}, \mathrm{kg} / \mathrm{t}$ & $2,70 \times 10^{-2}$ formaldehid, $\mathrm{kg} / \mathrm{t}$ & $1,16 \times 10^{-3}$ \\
\hline $\mathrm{NO}, \mathrm{kg} / \mathrm{t}$ & asetaldehid, $\mathrm{kg} / \mathrm{t}$ & $1,55 \times 10^{-5}$ \\
\hline $\mathrm{N}_{2}, \mathrm{~kg} / \mathrm{t}$ & akrolein, $\mathrm{kg} / \mathrm{t}$ & $1,34 \times 10^{-7}$ \\
\hline $\mathrm{PM} 10, \mathrm{~kg} / \mathrm{t}$ & $6,03 \times 10^{-5}$ propanal, $\mathrm{kg} / \mathrm{t}$ & $3,07 \times 10^{-6}$ \\
\hline $\mathrm{PM} 2,5, \mathrm{~kg} / \mathrm{t}$ & $2,75 \times 10^{-5}$ aseton, $\mathrm{kg} / \mathrm{t}$ & $3,07 \times 10^{-6}$ \\
\hline $\mathrm{H}_{2} \mathrm{~S}, \mathrm{~kg} / \mathrm{t}$ & butanal, $\mathrm{kg} / \mathrm{t}$ & $1,34 \times 10^{-7}$ \\
\hline $\mathrm{SO}_{2}, \mathrm{~kg} / \mathrm{t}$ & $2,57 \times 10^{-3}$ pentanal, $\mathrm{kg} / \mathrm{t}$ & $1,34 \times 10^{-7}$ \\
\hline $\mathrm{UHC}, \mathrm{kg} / \mathrm{t}$ & $4,45 \times 10^{-2}$ hexanal, $\mathrm{kg} / \mathrm{t}$ & $1,34 \times 10^{-7}$ \\
\hline $\mathrm{As}, \mathrm{kg} / \mathrm{t}$ & $5,35 \times 10^{-9}$ Benzaldehid, $\mathrm{kg} / \mathrm{t}$ & $1,74 \times 10^{-9}$ \\
\hline $\mathrm{Cd}, \mathrm{kg} / \mathrm{t}$ & $2,67 \times 10^{-10} \mathrm{NH}_{3}-\mathrm{N}, \mathrm{kg} / \mathrm{t}$ & $4,31 \times 10^{-2}$ \\
\hline $\mathrm{Co}, \mathrm{kg} / \mathrm{t}$ & $2,81 \times 10^{-8} \mathrm{~N}_{2} \mathrm{O}-\mathrm{N}, \mathrm{kg} / \mathrm{t}$ (direct) & $2,62 \times 10^{-2}$ \\
\hline $\mathrm{Cr}, \mathrm{kg} / \mathrm{t}$ & $2,41 \times 10^{-8} \mathrm{~N}_{2} \mathrm{O}-\mathrm{N}, \mathrm{kg} / \mathrm{t}$ (indirect) & $4,33 \times 10^{-4}$ \\
\hline $\mathrm{Cu}, \mathrm{kg} / \mathrm{t}$ & $4,14 \times 10^{-8} \mathrm{NO}-\mathrm{N}$ (NOx), kg/t & $1,71 \times 10^{-4}$ \\
\hline $\mathrm{Hg}, \mathrm{kg} / \mathrm{t}$ & $1,60 \times 10^{-8} \mathrm{NO}_{2}-\mathrm{N}, \mathrm{kg} / \mathrm{t}$ & - \\
\hline $\mathrm{Mn}, \mathrm{kg} / \mathrm{t}$ & $2,54 \times 10^{-8} \mathrm{~N}_{2}-\mathrm{N}, \mathrm{kg} / \mathrm{t}$ & $1,10 \times 10^{-2}$ \\
\hline $\mathrm{Ni}, \mathrm{kg} / \mathrm{t}$ & $3,07 \times 10^{-8}$ & - \\
\hline
\end{tabular}

Pengurangan emisi gas metana dapat dilakukan dengan mengganti outdoor storage menjadi inhouse storage. Berdasarkan laporan Hamelin dkk. (2013) emisi gas $\mathrm{CH}_{4}$ yang dihasilkan oleh inhouse storage lebih kecil daripada outdoor storage. Selain itu, pengurangan emisi gas metana dapat juga dilakukan dengan mengganti semua bahan bakar fosil yang terdapat di unit BPG dengan biogas, diharapkan dengan ini cukup mampu mengurangi karbondioksida yang terbentuk.

Pembahasan sebelumnya menunjukkan bahwa BPG sebagai salah satu unit produksi energi terbarukan berbasis limbah di Indonesia memiliki dampak lingkungan yang relatif rendah. Hal ini memperlihatkan bahwa teknologi biogas power plant dengan anaerobic digestion merupakan proses yang menjanjikan untuk digunakan sebagai teknologi pengolahan limbah sekaligus pemanen energi limbah.
Tabel 3. Beban lingkungan Biogas Power Plant Gamping

\begin{tabular}{lr}
\hline Kategori & \multicolumn{1}{c}{ Nilai hasil } \\
\hline GWP, kg CO${ }_{2}$ eq/t & 81,95 \\
FAETP, kg 1,4 DCBeq & 0,0098 \\
HTP, kg 1,4 DCBeq/t & 0,0109 \\
EP, $\mathrm{Kg} \mathrm{PO}_{4}^{3-}$ eq/t & 0,02 \\
$\mathrm{AP}, \mathrm{Kg} \mathrm{SO}_{2}$ eq/t & 0,07 \\
\hline
\end{tabular}

\subsection{Analisis Perbandingan Studi LCA dengan Sistem Sejenis}

Gambar 6 dan 7 menunjukkan analisis perbandingan lima dampak lingkungan (GWP, FAETP, HTP, EP dan AP) antara BPG dengan SBM, ISADP, OPM, dan OADM. Data-data dari SBM diperoleh dari Jin dkk. (2015), sementara ISADP, OPM, dan OADM diperoleh dari Opatokun dkk. (2017). Hasil analisis menunjukkan bahwa dampak lingkungan yang dihasilkan BPG dibandingkan dengan model produksi energi terbarukan yang lain tidak begitu nampak perbedaan yang signifikan kecuali pada dampak GWP. Dampak GWP yang dihasilkan oleh BPG masih lebih rendah bila dibandingkan dengan model lainnya. Hal ini dikarenakan jenis limbah bahan baku BPG adalah limbah buah yang relatif lebih aman untuk lingkungan. Limbah buah lebih mudah terurai dan kandungan zat berbahanya relatif lebih sedikit, selain itu BPG menggunakan unit proses yang hemat energi sehingga emisi yang dihasilkan lebih rendah. Secara keseluruhan dari empat model yang dibandingkan dengan BPG, sebagian besar memiliki dampak GWP terhadap lingkungan. Meskipun demikian, nilai ini menurut Opatokun dkk. (2017) dan Chen dkk. (2017) masih jauh lebih rendah bila dibandingkan dengan dampak GWP yang dihasilkan oleh Tempat Pembuangan Akhir (TPA). 

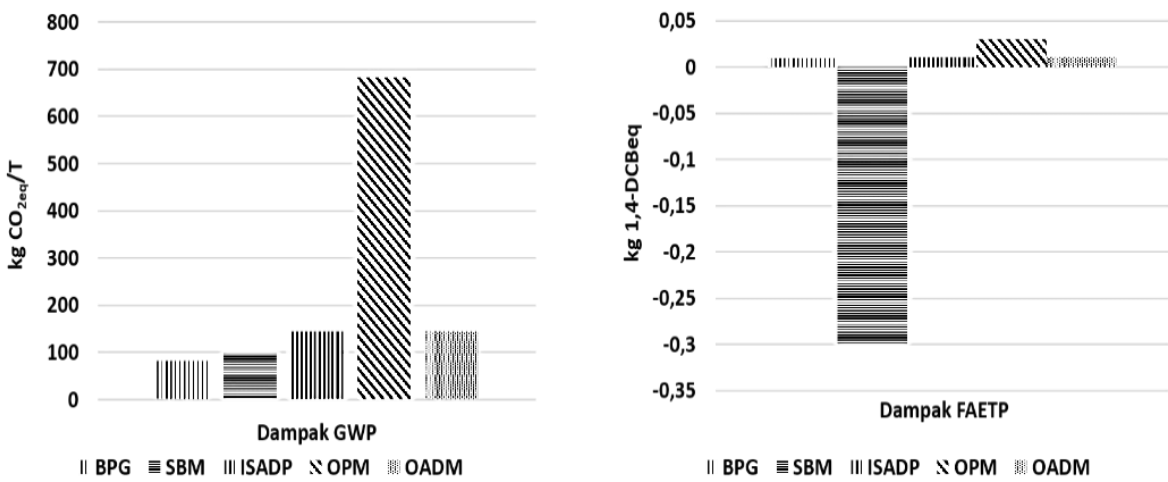

Gambar 6. Hasil perbandingan dampak lingkungan GWP dan FAETP
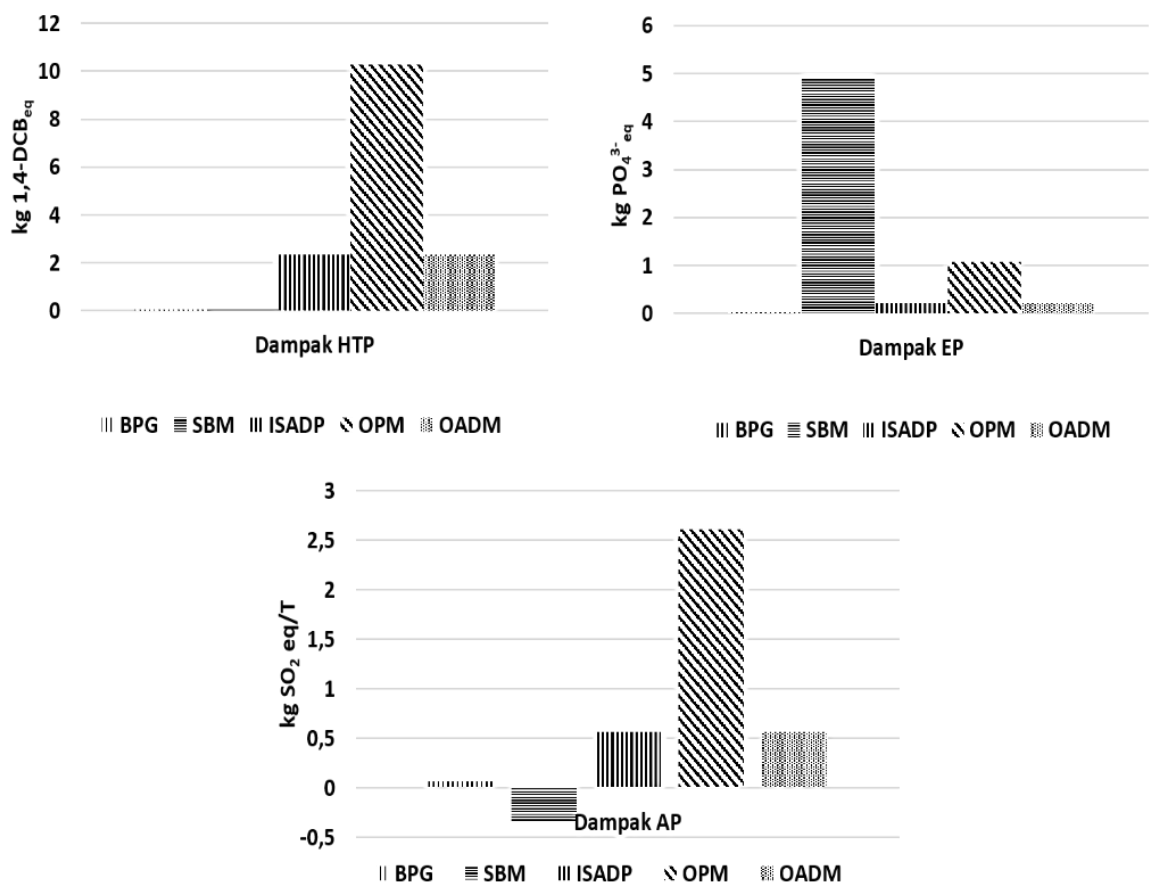

Gambar 7. Hasil perbandingan dampak lingkungan HTP, EP dan AP

Nilai dampak GWP yang lebih tinggi daripada dampak yang lain menunjukkan bahwa dampak ini memainkan peranan penting dalam penilaian dampak lingkungan produksi energi terbarukan berbasis limbah. Oleh karena itu pengendalian dampak GWP dengan melakuan penyesuaian dalam operasi proses merupakan pendekatan penting dalam pengendalian dampak lingkungan secara keseluruhan sistem BPG.

Salah satu cara untuk mengurangi beban lingkungan dari sistem BPG dapat dilakukan dengan meningkatkan produksi biogas (Jin dkk., 2015). Hal ini dikarenakan pemanfaatan energi terbarukan dapat dikompensasikan untuk mengurangi dampak lingkungan akibat penggunakan energi konvensional. Jin dkk.
(2015) menyebutkan bahwa penurunan produksi biogas sebesar $20 \%$ dapat meningkatkan dampak AP sebesar 28\%. Namun hal ini tidak dapat dilakukan secara parsial karena sangat memungkinkan tindakan ini dapat menyebabkan penurunan dampak lingkungan yang satu namun meningkatkan dampak lingkungan yang lain, maka diperlukan analisis yang lebih detail agar didapatkan komposisi yang sesuai.

Hasil analisis perbandingan ini menunjukkan bahwa BPG dan berbagai model produksi energi terbarukan berbasis limbah masih memerlukan peningkatan dan pengoptimalan teknologi untuk mengendalikan dampak GWP yang masih terjadi pada proses tersebut. 


\section{Kesimpulan}

Studi life cycle assessment pada sistem pembangkit energi listrik berbasis sampah buah pada biogas power plant di Pasar Gemah Ripah Gamping Sleman, Yogyakarta, menunjukkan bahwa dari kelima jenis emisi, emisi GWP memiliki dampak lingkungan yang paling signifikan $\left(81,95 \mathrm{kgCO}_{2}\right.$-eq/ton) dan merupakan faktor dominan pada sistem BPG dan keempat model yang lain. Emisi lainnya memiliki nilai EI yang lebih rendah. Analisis lebih lanjut menunjukkan bahwa unit pembangkit listrik dan unit penyimpanan digestate adalah kontributor utama untuk dampak lingkungan. Menurut analisis perbandingan, baik BPG, SBM, ISADP, OPM atau OADM, dampak GWP merupakan faktor kunci dalam pengurangan dampak lingkungan dari sistem. Melalui analisis dampak lingkungan dari produksi energi terbarukan berbasis limbah, BPG, dapat diidentifikasi bahwa sistem pembangkit listrik dan penyimpanan digestate sebagai sistem kunci yang mempengaruhi beban lingkungan. Peningkatan tingkat teknologi dari produk subsistem daur ulang, pembangkit listrik dan penyimpanan digestate secara signifikan dapat mengurangi beban lingkungan. Studi lebih lanjut berupa pengembangan model yang lebih komprehensif dengan mempertimbangkan kajian ekonomi, sosial dan faktor-faktor lain diperlukan untuk mengkaji lebih detail.

\section{Daftar Notasi}

$$
\begin{aligned}
\mathrm{LCA} & =\text { life cycle assessment } \\
\mathrm{LCIA} & =\text { life cycle inventory analysis } \\
\mathrm{LCAI} & =\text { life cycle assessment interpretation } \\
\mathrm{LCI} & =\text { life cycle impact } \\
\mathrm{EI} & =\text { environtmental impact } \\
\mathrm{PGR} & =\text { Pasar Gemah Ripah } \\
\mathrm{BPG} & =\text { Biogas Plant Gamping } \\
\mathrm{SBM}= & \text { Suazhou biogas model } \\
\mathrm{ISADP}= & \text { integrated system anaerobic } \\
& \text { digestion and pyrolisis } \\
\mathrm{OPM}= & \text { Opatokun pyrolisis model } \\
\mathrm{OADM}= & \text { Opatokun anaerobic digestion } \\
&
\end{aligned}
$$

$$
\begin{array}{ll}
\text { GWP } & =\text { global warming potential } \\
\text { FAETP } & =\text { fresh water ecotoxicity potential } \\
\mathrm{HTP} & =\text { human toxicity potensial } \\
\mathrm{AP} & =\text { acidification potential } \\
\mathrm{EP} & =\text { euthrophication potential } \\
\mathrm{M} & =\text { moisture } \\
\mathrm{VS} & =\text { volatile solid } \\
\mathrm{DM} & =\text { dry matter }
\end{array}
$$

\section{Ucapan Terima Kasih}

Penulis mengucapkan terimakasih kepada Direktorat Riset dan Pengabdian Masyarakat, Direktorat Jenderal Riset dan Pengembangan, Kementerian Riset, Teknologi dan Pendidikan Tinggi atas skema PTUPT dengan nomor perjanjian 1941/UN1/DITLIT/DIT-LIT/LT/2018. Penulis juga menyampaikan terima kasih atas dukungan dari mitra, Koperasi Gemah Ripah, Gamping Sleman, Yogyakarta.

\section{Daftar Pustaka}

Ahn, H. K., Smith, M.C., Kondrad, S.L., and White, J.W., 2010, Evaluation of biogas production potential by dry anaerobic digestion of switchgrass-animal manure mixtures, Appl. Biochem. Biotechnol., 160(4), 965-975.

Ariyanto, T. Cahyono, R.B., Vente, A Mattheij, S. Millati, R., Sarto. Taherzadeh, M.J. and Syamsiyah, S. 2017, Utilization of fruit waste as biogas plant feed and its superiority compared to landfill, Int. J. Technol., 8(8), 1385.

Cahyari, K. and Putra, R., 2009, Process Design and Economic Evaluation of Indonesian Fruit Market Waste to Biogas and Fish Feed, Master Thesis. University of Borås, Borås.

Chen, L., Cong, R.G., Shu, B., and Mi, Z.F., 2017, A sustainable biogas model in China: The case study of Beijing Deqingyuan biogas project, Renew. Sustain. Energy Rev., 78(April), 773-779.

Chen, T., Shen, D., Jin, Y., Li, H., Yu, Z., Feng, H., Long, Y., and Yin, J., 2017, Comprehensive evaluation of environ- 
economic benefits of anaerobic digestion technology in an integrated food waste-based methane plant using a fuzzy mathematical model, Appl. Energy. Elsevier, 208(September), 666-677.

Codina Gironès, V., Moret, S., Peduzzi, E., Nasato, M., and Maréchal, F., 2017, Optimal use of biomass in large-scale energy systems: Insights for energy policy, Energy, 137, 789797.

Cong, R. G., 2013, An optimization model for renewable energy generation and its application in China: A perspective of maximum utilization, Renew. Sustain. Energy Rev. Elsevier, 17, 94-103.

Dewan Energi Nasional, 2014, laporan Dewan Enrgi Nasional 2014. available at https://www.den.go.id/index.php/publikasi/do wnload $/ 23$.

Hamelin, L. Baky, A., Cano-Bernal, J., Grönroos, J., Kuligowski, K., Pehme, S., Rankinen, K, Skura, D., Wenzel, H., Wesnæs, M., and Ziolkowsky, M., 2013, Reference life cycle assessment scenarios for manure management in the Baltic Sea Regions - An assessment covering six animal production, five BSR countries, and four manure types, available at

http://www.balticmanure.eu/download/Reports/lc areference_report_wp5_web.pdf,(December), pp. 1-77.

Heijungs, R. Heijungs, R., Guinee, J.B., Huppes, G., Lankreijer, R.M., Udo, De Haes, Sleeswijk, A.W., Ansems, A.M.M., Eggels, P.G., Duit, R., and Goede, H.P., 1992, Environmental Life Cycle Assessment of Products - Vol 2: Backgrounds. Centrum voor Milieukunde, Den Haag.

Hua, Y., Oliphant, M. and Hu, E. J., 2016, Development of renewable energy in Australia and China: A comparison of policies and status, Renew. Energy, 85, 1044-1051.

IPCC, 2006, Intergovernmental Panel on Climate Change 2006 IPCC Guidelines for National Greenhouse Gas, Expert Meet. Rep.,1-20.

Jin, Y. Chen, T., Chen, X., and Yu, Z., 2015 , Life-cycle assessment of energy consumption and environmental impact of an integrated food waste-based biogas plant', Appl. Energy. 151, 227-236.

Kaparaju, P. Buendia, I., Ellegaard, L., and Angelidakia, I., 2008, Effects of mixing on methane production during thermophilic anaerobic digestion of manure: Lab-scale and pilot-scale studies, Bioresour. Technol., 99(11), 4919-4928.

Kloepffer, W., 2008, Life cycle sustainability assessment of products (with Comments by Helias A. Udo de Haes, p. 95), Int. J. Life Cycle Assess., 13(2), 89-94.

Kothari, R. Pandey, A. K., Kumar, S., Tyagi, V. V., and Tyagi, S. K. 2014, Different aspects of dry anaerobic digestion for bio-energy: An overview', Renew. Sustain. Energy Rev, 39, 174-195.

Lijó, L. González-García, S., Bacenetti, J., and Moreira, M. T., 2017, The environmental effect of substituting energy crops for food waste as feedstock for biogas production, $\mathrm{j}$. energy, 137,1130-1143.

Makaruk, A., Miltner, M. and Harasek, M., 2013, Biogas desulfurization and biogas upgrading using a hybrid membrane system: Modeling study, Water Sci. Technol., 67(2), 326-332.

Miltner, M., Makaruk, A. and Harasek, M., 2017, Review on available biogas upgrading technologies and innovations towards advanced solutions, J. Clean. Prod., 161, 1329-1337.

Nasir, I. M., Ghazi, T. I. M. and Omar, R., 2012, Production of biogas from solid organic wastes through anaerobic digestion: A review, Appl. Microbiol. Biotechnol., 95(2), 321-329. Nielsen, M., Nielsen, O., Kenneth, and Plejdrup, M., 2014, Danish Emission Inventories. Available at: http://dce2.au.dk/pub/SR102.pdf.

Nielsen, M. Nielsen, O-K., Plejdrup, M., and Hjelgaard, K., 2010, Danish emission inventories for stationary combustion plants: Inventories until 2008, NERI Technical Report no. 795. National Environment Research Institute: Aarhus University.

Niesner, J., Jecha, D. and Stehlík, P., 2013, Biogas upgrading technologies: State of art 
review in european region, Chem. Eng. Trans., 35, 517-522.

Nurrihadini, 2009, Karakterisasi Sampah Buah Pasar Buah Gamping sebagai Bahan Baku Alternatif Produksi Biogas, Skripsi Sarjana, Universitas Gadjah Mada, Yogyakarta.

Opatokun, S. A., Lopez-Sabiron, A., Ferreira, G., and Strezov, V., 2017, Life Cycle Analysis of Energy Production from Food Waste through Anaerobic Digestion, Pyrolysis and Integrated Energy System, Sustainability, 9(10), 1804.

Pathak, H. Jain, N., Bhatia, A., Mohanty, S., Gupta, N., 2009, Global warming mitigation potential of biogas plants in India', Environ. Monit. Assess., 157(1-4), 407-418.

Poeschl, M., Ward, S. and Owende, P. 2010, Prospects for expanded utilization of biogas in Germany, Renew. Sustain. Energy Rev., 14(7), 1782-1797.

Rahmani, P., Hartono, D. M. dan Kusnoputranto, H., 2013, Kajian Kelayakan Pemanfaatan Biogas Dari Pengolahan Air Limbah Untuk Memasak, Ilmu Lingkung., 11(2), 132-140.

Saady, N. M. C. and Massé, D. I. ,2015, Impact of organic loading rate on the performance of psychrophilic dry anaerobic digestion of dairy manure and wheat straw: Long-term operation., Bioresour. Technol., 182, 50-7.

Scano, E. A. Asquer, C., Pistis, A., Ortu, L., Demontis, V., and Cocco, D., 2014, Biogas from anaerobic digestion of fruit and vegetable wastes: Experimental results on pilot-scale and preliminary performance evaluation of a full-scale power plant, Energy Convers. Manag., 77, 22-30.
Schiavon Maia, D. C. Cardoso, F.H., Frare, L. M., Gimenes, M. L, Pereira, N. C., 2014, Purification of Biogas for Energy Use, Iconbm: Int. Conf. Biomass, Pts 1 2, 37(1), 643-648.

Sitorus, B., Sukandar dan Panjaitan, S. D., 2013, Biogas recovery from anaerobic digestion process of mixed fruit-vegetable wastes, Energy Procedia., 32, 176-182.

Weiland, P., 2003, production and energetic use of biogas from energy crops and wastes in Germany, Appl. Biochem. Biotechnol., 109(1-3), 263-274.

Williams, R.B., Davis, Ely, C., Martynowicz, T., dan Kosusko M., 2016, Evaluating the Air Quality, Climate \& Economic Impacts of Biogas Management Technologies', (September). Available at: https://nepis.epa.gov/Exe/ZyPDF.cgi/P100QC XZ.PDF?Dockey=P100QCXZ.PDF.

Zalizar, L., Relawati, R. dan Ariadi, B. Y.,2013, Potensi produksi dan ekonomi biogas serta implikasinya pada kesehatan manusia, ternak dan lingkungan', J. Ilmu-Ilmu Peternak., 23(3), 32-40.

Zhang, Q., Hu, J. and Lee, D. J., 2016, Biogas from anaerobic digestion processes: Research updates, Renew. Energy, 98,108-119. 